\title{
Spatial Analysis of Sade Traditional Hamlet in Lombok Island, Indonesia: The Alteration of Sasak Tribe's Traditional Living Space
}

\author{
Dini Aiko Subiyantoro ${ }^{1}$, Yasufumi Uekita ${ }^{2}$, Shigeo Oodaira $^{3}$, Kunihiko Ono ${ }^{4} \&$ Koji Sato \\ ${ }^{1}$ Master's Program in World Heritage Studies, University of Tsukuba, Japan \\ ${ }^{2}$ Faculty of Art and Design, University of Tsukuba, Japan \\ ${ }^{3}$ Cooperative Organization for the Study of Traditional Building Techniques, Japan \\ ${ }^{4}$ Faculty of IT and Business, Cyber University, Japan \\ ${ }^{5}$ Department of Social Research, National Museum of Ethnology, Japan \\ Correspondence: Dini Aiko Subiyantoro, World Heritage Studies, University of Tsukuba, Joint Use Office-5, \\ Tennodai 1-1-1, Tsukuba City, 305-8577, Japan. Tel: 090-3685-2704. E-mail: diniaikos@gmail.com
}

Received: February 7, 2019

Accepted: March 9, 2019

Online Published: April 4, 2019

doi:10.5539/ach.v11n2p11

URL: https://doi.org/10.5539/ach.v11n2p11

\begin{abstract}
Hundred years ago, vernacular architecture once triumphed. Unfortunately, poverty and low education bring people facing difficulties in understanding their own culture, building techniques, and village management. This problem then leads them to a bigger issue regarding the alteration of culture and traditional architecture. Among all vernacular architecture in Indonesia, Sasak traditional architecture is one of the unique architectures that still exist until now. However, globalization issue leads the alteration of vernacular architecture includes Sasak tribe culture and traditional village in Lombok island, including the traditional houses. This paper takes Sade Traditional Hamlet as a research subject to provide a deeper understanding of the importance of cultural values of Sasak's living space and settlement. This research shows that the living space and culture of the Sasak tribe in Sade hamlet has evolved and transformed due to the space necessity and financial ability. Among the total 68 houses, 55.8\% are the original houses of Sasak people in Sade hamlet, Bale Tani, 38.2\% are the traditional modified houses, Bale Bontar, and 6\% are the transitional houses, Bale Kodong. Gradually, Bale Tani change to Bale Bontar house. However, Bale Tani could still be preserved by the system of pattern relatives in the family and awiq-awiq as customary law. A deeper understanding of the house preservation, traditional material, and cultural values of Bale Tani should be taken to create a sustainable conservation method.
\end{abstract}

Keywords: Vernacular Architecture, Spatial Analysis, Conservation, Sade Hamlet, Lombok, Indonesia

\section{Introduction}

Indonesia is a home for over 300 ethnic groups and an archipelago of 17,508 islands. It is the world's largest Muslim-majority nation with a total population of 242 million people. Among all island in Indonesia, an Islamic ethnic group called Sasak, live in Lombok island, struggle in holding their ancestral heritage and its cultural values. Limited record and minimum concern of Sasak culture make it difficult to determine an appropriate method in preserving its cultural and architectural heritage. In addition, conservation activities in Indonesia are only focusing on stone architecture. During the colonial era in 1901, the first committee, Commisie in Nederlandsche-Indie voor Oudheidkundige Orderzoek op Java en Madura, was created to manage Indonesian heritage. After that, Monumenten Ordonnantie no. 238 of 1931, was decreed as the first law regarding cultural heritage. It later became the basis for the establishment of law no.5 of 1992 (UU Cagar Budaya no.5 tahun 1992), which then amended to the law no.11 of 2010 (Aziz, 2014). Among Indonesian architect, conservation issue became more popular as the Old Town Batavia (Jakarta) revitalized by Ali Sadikin in 1970th. Although the conservation issue was very popular, the specific conservation methods for traditional villages in Indonesia still not regulated. The absence of architectural conservation policy in Indonesia leads us to a bigger problem, the alteration, and reduction of our heritage.

Sasak tribe has a unique concept in their settlement and dwellings. Observed deeply, we can see a similar pattern in their traditional settlement. However, in this modern era, many of new settlements are starting to spread along the Lombok Island. Some of the traditional settlement still trying to keep the authenticity of both of its physical 
and non-physical value. Sade hamlet is a traditional settlement that considered to be one of those which still keeps their tradition in their settlement and daily life. Entering $21^{\text {st }}$ century, Sade people starting to consider the necessity of more space in their house and settlement. The number of traditional houses rapidly increased, following the growth of the population. On the 2000s, Sade hamlet receive some support from the Indonesian government with well and cement. Moreover, in 2015, they also receive revitalization projects from the government. However, it not yet known if the government understand the appropriate method of revitalization or not, since the local government or the village does not have policy in terms of traditional house conservation. Therefore, this research expected to provide a deeper understanding of the importance of cultural values of Sasak's living space and settlement. Thus, can help preserve cultural heritage along with the values in it.

Most of the research about Lombok usually concerned on the religion aspect or tourism development. Spatial research usually focuses on the northern or western Lombok. A research has been done by Japanese researcher, Wakita (1995), about space organization in the settlement of Bayan village in North Lombok, and to find the connection between houses and Berugak. There is also other research by Wirata (2013) about Sasak's tribe traditional house transformation in Segenter hamlet in North Lombok. Meanwhile, the purposes of this research are to identify the alteration tendency of Sasak traditional house and how the Sasak community preserve their traditional houses in correlation with the customary law. This research expected to provide a deeper understanding of the importance of cultural values and in-depth knowledge of the value of Sasak's living space and settlement. Thus, can help preserve cultural heritage along with the values in it.

\section{Research Method}

\subsection{Literature Study}

Literature study from books, journal, and articles were conducted to enrich the information about Sade hamlet, the author collected some data about the history of the Sasak's tribe and its religion, Sasak's tribe culture and architecture, and other secondary data. The studies from the previous research are also important to enrich the information for this research. The author also conducts research to some universities in Indonesia to investigate the related research to verify the authenticity of this research.

\subsection{Site Survey and Data Sampling}

Three times field survey on March, July, and September 2018 were conducted to collect the current data through house measurement and interview. 17 sample of the traditional house was collected along with the house measurement, data of the space function, and interview with the house owner about the house, to record the current detailed data about the space utilization and the modification that has been done in every traditional house. This data was analyzed to obtain the space pattern in the Sasak's tribe traditional house.

\subsection{Data Collecting from Local Government}

Data from the local government and interview also collected to understand the basic information about the village, the government's program from the village development, and how the government supports the village preservation.

\subsection{Data Analysis}

Data analysis were done to identify the house's typology and to identify remain part and/or the modification in traditional houses.

\section{Overview of Lombok Island and Sade Hamlet}

Lombok Island covers an area of 4,700 $\mathrm{km}^{2}$ and inhabited by Sasak people for around 2.4 million residents and about $85 \%$ of the people are indigenous ethnic Sasak Muslim (Budiwanti, 2012). The area of Lombok Island divided into mountainous, hilly, and flat region. This island has some traditional villages that remain until now, spread among all areas of the island. The traditional villages in Lombok Island have a similar pattern in terms of its architecture, influenced by their ancestor's belief, Wetu Telu. Although now, the Wetu Telu believers can only be found in the Northern area of Lombok, the traditional houses on Central and East Lombok still exist. However, the traditional houses of East Lombok are already not occupied. Currently, Sade hamlet has the biggest number of traditional houses and population, and it is expected that all of the house materials are still traditional in most of its part. 


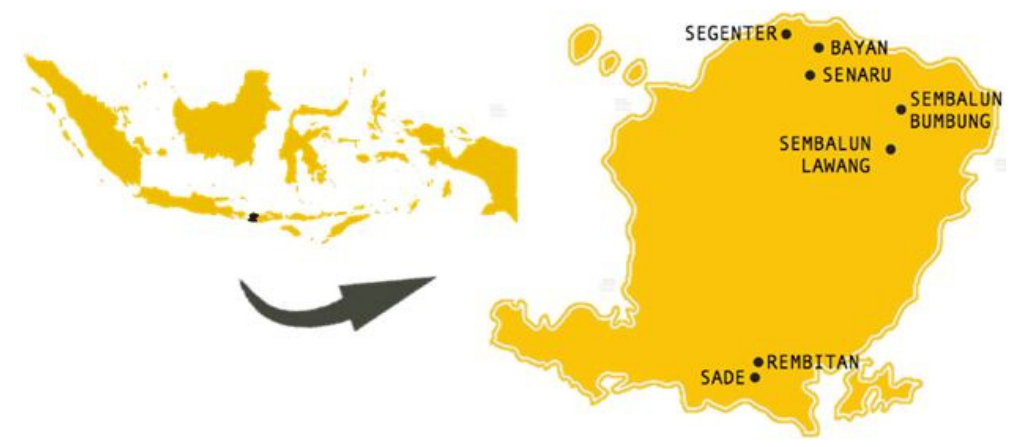

Figure 1. The location of traditional villages in Lombok Island

The hamlet of Sade is a traditional hamlet of Lombok indigenous Sasak people that located in Rembitan Village, Pujut sub-district, Central Lombok, Indonesia. This hamlet is directly accessible from the main road, so visitors and tourists can easily come to visit. The distance from Sade hamlet to Mataram as the provincial capital is around $40 \mathrm{~km}$, while the distance to Lombok International Airport is around $11 \mathrm{~km}$. Sade hamlet located in a dry land with a low number of rainfalls with the average of $84 \mathrm{~mm} 3$ per year and the average of rainy days is 7 days (2015) with the average temperature is 24-32 degrees Celsius. This dry condition causes limited types of flora, as well as the difficulties of agriculture in this area. As for the fauna, most people in Sade hamlet raising cattle and goats, and buffalo as their ritual animal. Currently, Sade is inhabited by 529 Sasak people, including 262 men and 267 women (Suarsana, 2015), and covers an area of 1.79 hectares with 68 traditional houses. Along with the houses, there are also other facilities inside the hamlet, such as traditional mosque, multipurpose shelter (berugak), rice storage (alang), shops, and toilets.

Different from another hamlet and village that built on the flat area, the settlement in Sade built circular because it was built on the hill. It was the habit of the Sasak tribe's ancestor in the past to always looking for a high place to live, so they can be closer to the center point of cosmic. And the closer they are to the cosmic, the faster they can reach the spiritual point and the closer they can see the moon and the stars as their guide in understanding time and direction. For the Sasak people, Mount Rinjani has been seen as a center of spirituality and mysticism. Therefore, the orientation of the Sasak tribe's traditional houses is also based on the direction of Daya and Lauq. As a whole, the traditional houses are avoiding facing the Mount Rinjani direction. In the traditional settlement that located in north and south (such as Sade, Senaru, and Segenter village), the houses are facing the east and west direction, while in the settlement that located in the eastern part (such as Sembalun village), the houses are facing to the north and south direction. On the interview with the chief of Sade hamlet, there was a customary law called awiq-awiq that prohibited the Sasak people in building their house towards Mount Rinjani.

The traditional villages in Lombok Island have a similar pattern in terms of its architecture, influenced by their ancestor's belief, Wetu Telu. Although they have similar house form and materials, they have a different style of floorplan and different pattern of village site plan. In the traditional hamlet and villages in Northern area of Lombok, the traditional houses built directly on the ground, with a high level of space in the core as their sacred space. Meanwhile, in Central Lombok, the floor built in levels, following the form of the roof. However, the Sasak tribe's culture and their traditional villages have developed through several stages based on location, availability of material resources, economic condition, and globalization.
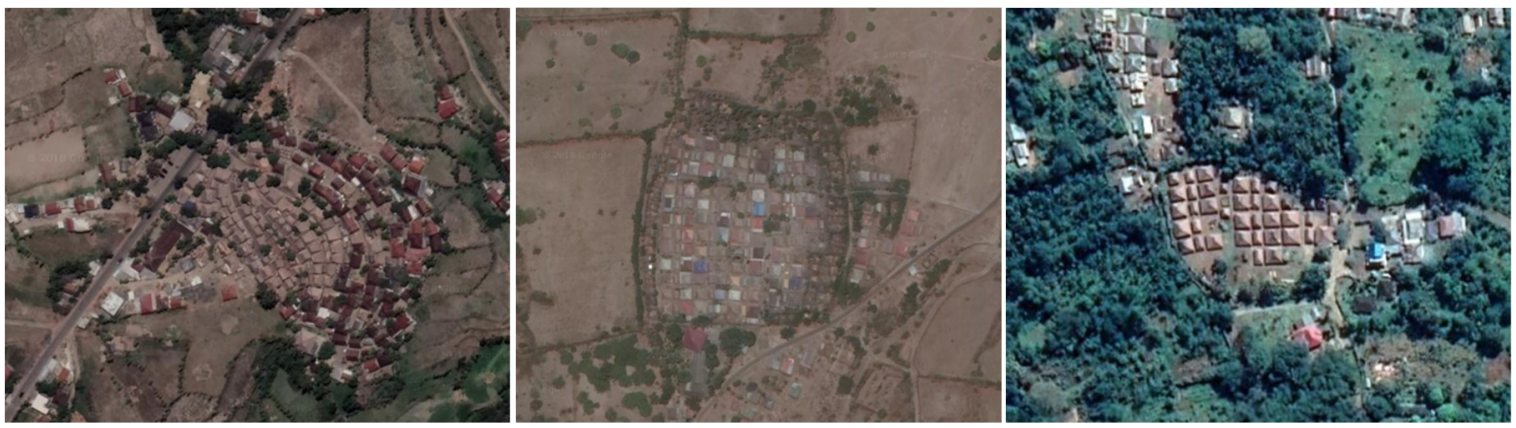

Figure 2. The difference of house arrangement in the traditional settlement in Lombok Island (from left to right: Sade hamlet, Segenter hamlet, and Senaru hamlet) 


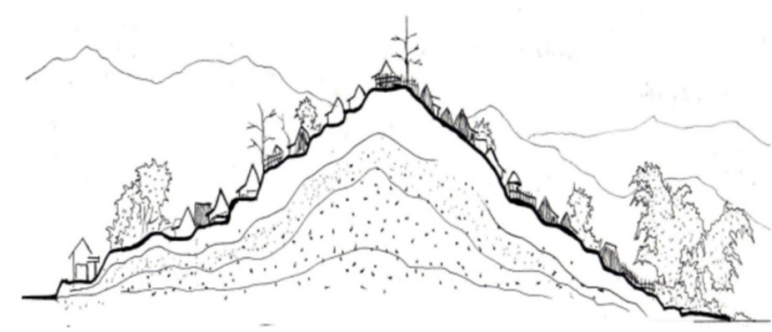

Figure 3. The section drawing of Sade village that located on the hill (Sukawi, 2010)

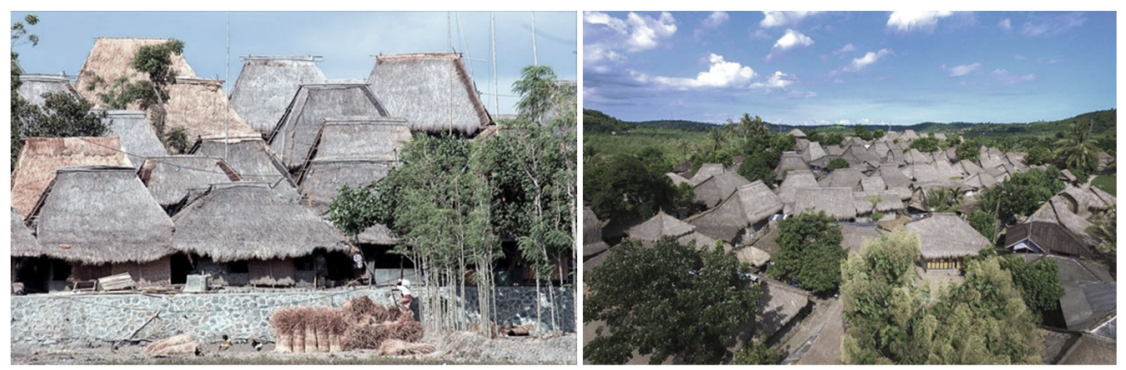

Figure 4. The roof of the traditional houses in Sade hamlet

Source: http://www.lombokmandalika.co.id/rumah-tradisional-suku-sasak-lombok-ntb-menarik-untuk-dikenal/

\section{Result: Spatial Analysis of Traditional Houses}

\subsection{House Typology and Utilization}

In Sasak language, house means Bale. Besides functioning as a house, Bale also considered as a micro social institution called Bale Langgaq (household) (Faturrahman, 2016). Generally, Bale that located on the coast are different from the bale that located in the mountain or hills. The land condition of the settlement affects the house character and layout. This pattern becomes a reference for us to interpret the traditional architecture of Sasak tribe as a result of a society's creative process in facing natural challenges and then becomes their identity. In this hamlet, the houses are still in traditional form and material. The bottom part is made from mixed soil, rice husk, and cow dung. The middle part, living space, using Timus wood (local strong wood) for the pillars (tekan) and woven bamboo for the wall (bedeq). Above it is the roof structure that constructed from bamboo that tied with a tree branch (Saot) and covered with rice straw (alang-alang).

This study was included three times survey in Sade hamlet on March 4th - 6th, June 29th - July 2nd, and September 22nd - 26th 2018. The survey recorded the house's typology of the traditional houses in Sade hamlet, the current condition of the hamlet, the number of the houses and the traditional buildings, the modifications, and the activities inside the house. Among the traditional houses, there are three types of Bale in Sade Hamlet, called Bale Tani (farmer's house), Bale Bontar (traditional modified house), and Bale Kodong (temporary transitional house). The survey recorded 68 traditional houses that include 38 Bale Tani, 26 Bale Bontar, and 4 Bale Kodong. This research will compare the spatial of 8 samples of Bale Tani and 8 samples of Bale Bontar.

- Houses (68 in total):
38 Bale Tani
26 Bale Bontar
4 Bale Kodong
- Additional facilities:
- 9 Berugak
(Multipurpose Shelter)
- 8 Alang (Rice storage)
- 26 Souvenir shops
- 1 Mosque
- 14 Toilets

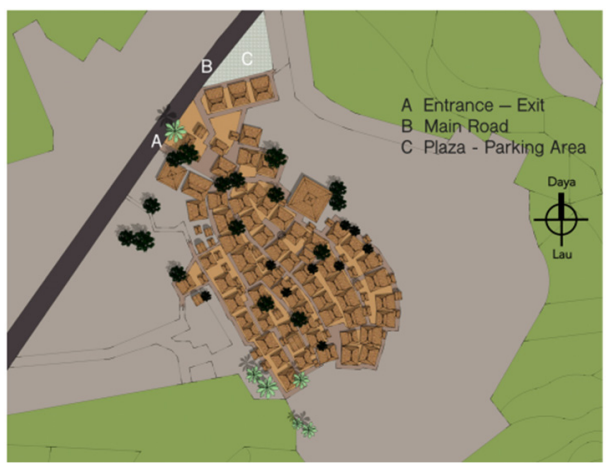

Figure 5. Site Plan of Sade Hamlet (Author, 2018)

Scale 1: 1800 


\subsubsection{Bale Tani (Farmer House)}

The first type is the original house of Sasak people in Sade hamlet called Bale Tani, which means farmer house. From 68 traditional houses in total, there are 38 Bale Tani houses in Sade Hamlet. 5 of it are considered to be the oldest Bale Tani house. The floor of Bale Tani built with levels, following the form of the roof. The traditional house of Sasak people contains a special concept regarding the spiritual aspect and commanding women. The mother and the daughter living in higher and safer space, as a symbol of respect and protection. Specifically, the space inside Bale Tani is divided into two, indoor part (Langen Dalem) and outdoor part (Langen Duah). The indoor part consists of Dalem Bale room, that used as kitchen and women bedroom, and Bale Dalem room that used as delivery room and unmarried women's bedroom.

The outdoor area consists of Sesangkok room that divided into the south (Sesangkok Lau) which faces the sea and north (Sesangkok Daya) area which facing the Mount Rinjani. To enter Bale Tani, there is only one access from one entrance. In total, there are only two doors in Bale Tani, entrance door and sliding door which connect Langen Duah and Langen Dalem area.

(a) Bale Dalem

Bale Dalem means 'a house inside the house'. This room is considered to be a sacred room. Sasak people in Sade hamlet really protect their daughter, because of their 'kidnapping' tradition in marriage system. The daughter or girl has to sleep in the back space of the house, a room without windows, and only have one access through the other room called Dalem Bale. This room is also functioned as a valuable storage room; as prayer room; and as a delivery room.

\section{(b) Dalem Bale}

Dalem Bale means 'inside the house'. This room functioned as a kitchen (pawon), offerings making room, and bedroom for a married woman, who either mother or grandmother. Dalem Bale connects the outdoor area and Bale Dalem room, which can also be said that this room is the second barrier to protect Bale Dalem. Inside the room, we can see a traditional stove from clay called Jangkih, and traditional cooking utensils that usually used for ritual and traditional ceremony. When Sasak people are going to do a ritual, such as Roah Klemak or Begawe, they prepare the offerings and foods in Dalem Bale room. To prepare the rice, they pound the rice husk with Alu, a 2 meters wood stick to pound, and Gendang, a big bucket from wood that used to store the rice husk. After the rice separated with its husk, the rice cooked with the traditional method using a traditional stove called Jangkih. When doing a ritual, Sasak people have to do every process with traditional method and using traditional utensils.

\section{(c) Sesangkok Lau and Sesangkok Daya}

Sesangkok room is divided into two areas, the south and the north. The south area called Sesangkok Lau, which refers to the direction of the sea, whereas the north area called Sesangkok Daya, which refers to the direction of the mountain. Sesangkok Daya functioned as a dining room, living room, and receiving room. When the neighbor or guest come to Bale Tani, they usually enter and gather in this area. Sometimes, the family from another village or house come to their relative's house and have lunch or dinner together along with some chit and chat. This Sesangkok Daya considered as a semi-public area.

Although located in the same area, Sesangkok Lau considered as a more private space than Sesangkok Daya. Here is the place where father or men usually sleep at night. At the daytime, it sometimes used by the women to take a nap with their babies. Moreover, when Sasak people dead, the body remains at home before burial and laid on the Sesangkok Lau with the head heading to Mount Rinjani direction (north). Before Islam enters this hamlet, the Sasak people of Sade hamlet lay the dead body here for one night.

\subsubsection{Bale Bontar (Round House)}

Bale Bontar, that means round-house, is a traditional modified house that was built starting from 1971, correlated to the economic condition of the Sasak community and space necessity, as the population was increasing. Bale Bontar has a similar form with Bale Tani, and some Bale Bontar also has multilevel space in the inside. However, Bale Bontar has more room than Bale Tani and different space order compared to Bale Tani. In Bale Bontar, there is no Langen Dalem (indoor area) and Langen Duah (outdoor area). The space of one of Bale Bontar is different from the other Bale Bontar house. The number of space and arrangement depends on the house owner. Different from Bale Tani, there is no Bale Dalem inside Bale Bontar. Bale Dalem in Bale Tani house is functioned as delivery room, valuable storage room, and girls (unmarried woman) bedroom. In Bale Bontar house, Bale Dalem is no longer exist. So, when the mother giving birth, they will use their parents or relatives house, the Bale Tani 
house. Furthermore, the valuable storage room moved to another room, and the girls will have their own bedroom. Although has a different floor plan with Bale Tani, Bale Bontar has room to prepare the offerings.
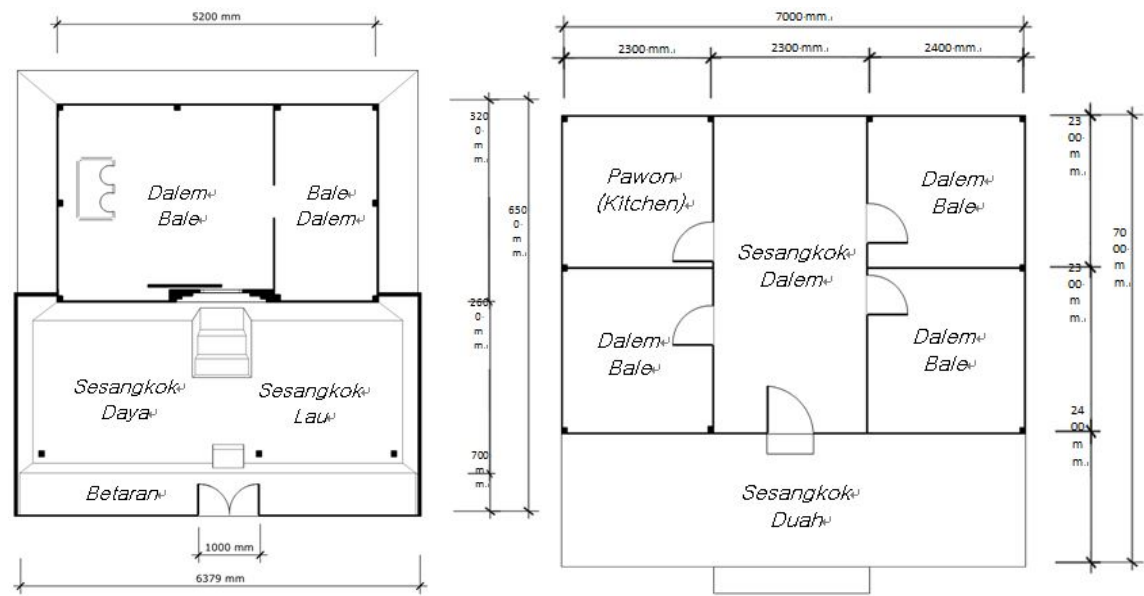

Figure 6. Left: Floor plan of the typical Bale Tani; Right: Floor plan of Bale Bontar (not typical)

Scale 1: 100

\subsection{Space Analysis}

\subsubsection{Bale Tani (Farmer House)}

The figures below explain about the location of 8 sample of Bale Tani and the space utilization.
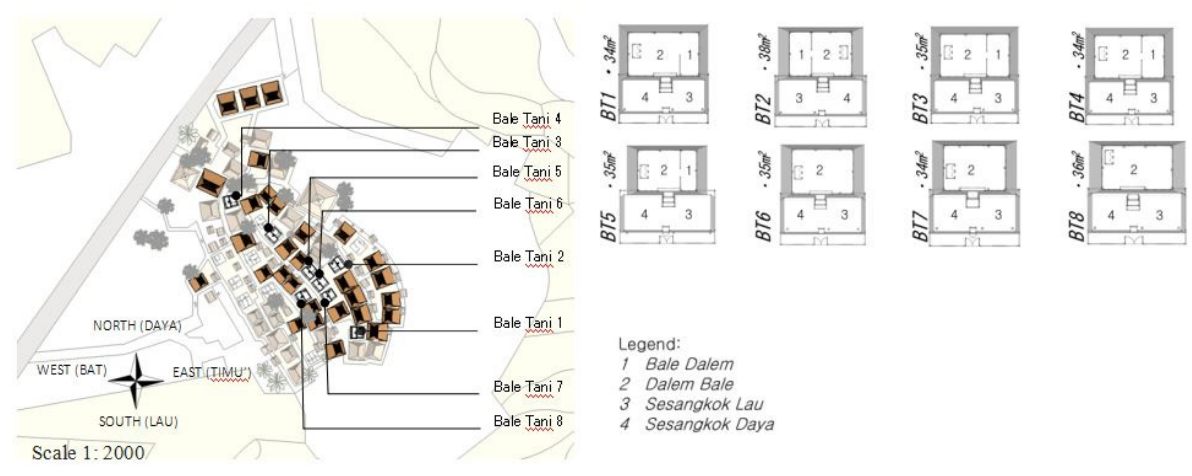

Figure 7. Left: Map of 8 sample of Bale Tani in Sade hamlet; Right: Floor plan of 8 sample of Bale Tani in Sade hamlet

Table 1. Activity in each space of Bale Tani house

\begin{tabular}{|c|c|c|c|c|c|c|c|c|c|}
\hline \multirow{2}{*}{$\begin{array}{l}\text { House } \\
\text { Type }\end{array}$} & \multirow[b]{2}{*}{ Room Function } & \multicolumn{8}{|c|}{ Activity in Each House } \\
\hline & & Вт1 & BT2 & втз & BT4 & BT5 & BT6 & BT7 & BT8 \\
\hline \multirow{12}{*}{ 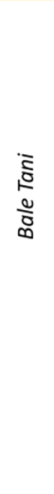 } & Father's Sleeping Room & 3 & 3 & 3 & - & 3 & - & 3 & 3 \\
\hline & Mother's Sleeping Room & 2 & 2 & 2 & 2 & 2 & - & 2 & 1 \\
\hline & Daughter's Sleeping Room & 1 & - & - & 1 & 1 & - & - & - \\
\hline & Son's Sleeping Room & 1 & 1 & 1 & - & 3 & 1 & - & 3 \\
\hline & Delivery Room & 1 & 1 & 1 & 1 & 1 & 1 & 1 & 1 \\
\hline & Storage & 1 & 1 & 1 & 1 & 1 & 1 & 1 & 1 \\
\hline & Kitchen & 2 & 2 & 2 & 4 & 2 & 4 & 2 & 2 \\
\hline & Rice Pounding Room & 2 & 2 & 2 & 2 & 2 & 2 & 2 & 2 \\
\hline & Receiving Room & 4 & 4 & 4 & 4 & 4 & 4 & 4 & 4 \\
\hline & Dining Room & 4 & 4 & 4 & 4 & 4 & 4 & 4 & 4 \\
\hline & Living Room & 4 & 4 & 4 & 4 & 4 & 4 & 4 & 4 \\
\hline & & & & & \multicolumn{3}{|c|}{ Ritual preparation space } & \multicolumn{2}{|c|}{$\begin{array}{l}\text { Room Name } \\
\text { (1): Bale Dalem } \\
\text { (2): Dalem Bale } \\
\text { (3): Sesanghok Lau } \\
\text { (4): Sesangkok Daya }\end{array}$} \\
\hline
\end{tabular}


Among 8 samples of Bale Tani, all sample have the same pattern for the floor plan. In these past years, the function of some rooms already changed, especially the sleeping room for each family member. In Bale Tani house, Bale Dalam used for the daughter's bedroom. But currently, many Bale Dalem room of the Bale Tani house used for a sleeping room for the son. This sometimes occurs because there is no daughter in the family, or because the daughter already got married. Therefore, this space usually used by the son or grandchildren. Among 8 houses, Bale Dalem in 4 houses used for son's sleeping room. This is allowed because Sasak people believe if they sleep and live in their birthplace, they will have a strong connection with their ancestor. However, men cannot enter this area when there is a giving birth process.

Dalem Bale room still functioned as kitchen and rice pounding room for offerings preparation. However, 2 of the houses not using this room as a kitchen. These 2 houses using Sesangkok Daya room for the kitchen because the woman owner has a health problem which makes her can barely move to the higher room. Whereas the other Bale Tani house only occupied by one man who rarely cooks by himself. Sesangkok Lau room, which functioned as father's and son's bedroom, being used as its function. Sesangkok Daya room, which functioned dining, living, and receiving room, also being used as its function.

\subsubsection{Bale Bontar (Traditional Modified House)}

The figures below will explain about the location of eight sample of Bale Bontar and the space utilization of each space.
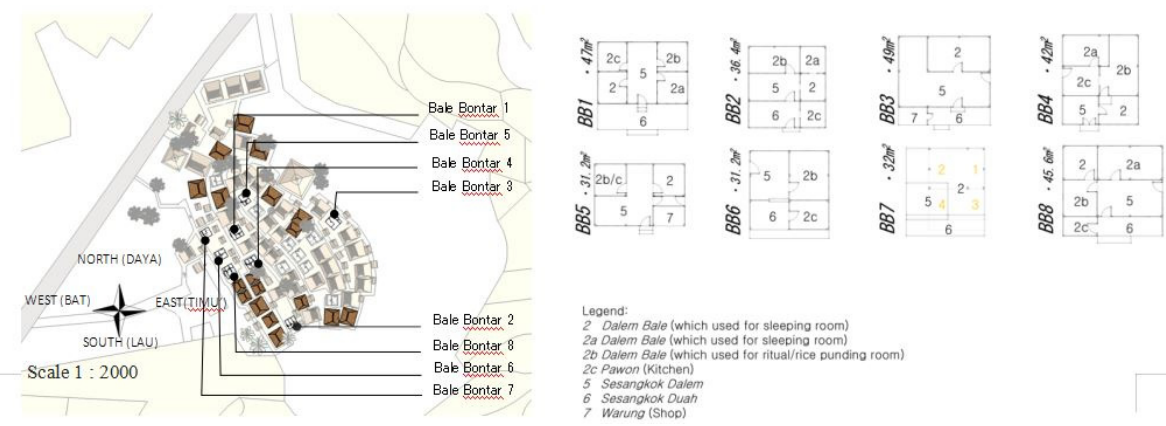

Figure 8. Left: Map of 8 sample of Bale Bontar in Sade hamlet; Right: Floor plan of 8 sample of Bale Bontar in Sade hamlet

Table 2. Activity in each space of Bale Bontar house

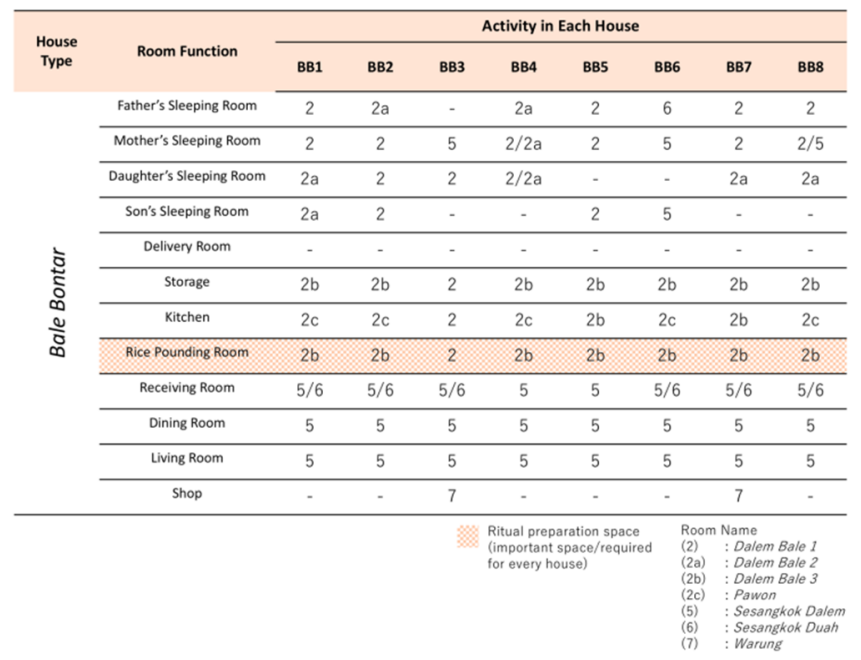

Among 8 samples of Bale Bontar, all sample have different patterns for the floor plan. However, the function of the spaces in all Bale Bontar house is quite the same. Bale Bontar usually has one or more Dalem Bale room. However, Bale Dalem is no longer exist in Bale Bontar. The room that functioned as Bale Dalem turned into an ordinary Dalem Bale, which used for girl's bedroom of valuable storage room, without the delivery room. The 
women who live in Bale Bontar usually will give birth at the Bale Tani that owned by their family or in the nearest hospital. In Bale Tani house, Bale Dalem used as a sleeping room for the girls, Dalem Bale used as a sleeping room for mother, and Sesangkok Lau used as a sleeping room for father and son. Whereas, in Bale Bontar house, parents mostly sleep together in the same room and children sleep in the different room. However, in the interviews with Bale Bontar occupants, some men also sometimes sleep in the outdoors to protect their family. Although most rooms of Bale Bontar made from cement floor, there is one room that required to be built with traditional materials, the offerings preparation room. This room, also called Dalem Bale, has to be constructed with traditional floor (mixed soil, rice husk, clay, and cow dung) and built without ceiling. In some houses, it separated with the modern kitchen called Pawon.

\subsection{Pattern Relatives}

As a Sasak family grows and expand, the children have to move out from their parent's house and built a new house after they got married. After the parents or father passed away, the last son must return to their parent's house and live there with their family. In other words, the house will be inherited to the youngest son in the family. In case there is no son in the family, the house will be inherited to their nephew. So basically, one house can only be occupied by one household. This system is one of the methods of how Sasak people preserves their traditional house.

\section{Conclusion}

This research shows that the living space of the Sasak tribe in Sade hamlet has evolved and transformed due to the space necessity and financial ability. Since it was first formed, traditional houses in Sade hamlet evolved from Bale Tani as original house, then Bale Kodong as a temporary transitional house, then to Bale Bontar as a modified traditional house. Among the total 68 houses, 55.8\% are Bale Tani, 38.2\% are Bale Bontar, and $6 \%$ are Bale Kodong. The comparative study reveals the alteration of the space pattern and the modifications in the house, spatial and structural.

Bale Tani has cultural values, unlike the Bale Bontar house. Different from Bale Bontar, Bale Tani considered as an important place for Sasak people's life because it contains a birthplace room, called Bale Dalem, and a death ritual room, Sesangkok Lau. Meanwhile, all samples of Bale Bontar house does not contain this kind of room, and they usually use their relative's Bale Tani house for giving birth or death ritual. This shows that Bale Tani is a crucial place for every stage of Sasak people's life, from born until death. Therefore, it must be preserved.

All of Bale Tani sample reveals the same pattern of floorplan, which is has Bale Dalem, Dalem Bale, Sesangkok Lau, and Sesangkok Daya. However, some houses have several methods in using those room. In Bale Tani, the indoor area (Bale Dalam and Dalam Bale room) considered as a woman's workplace and live, men rarely enter those areas. While the outdoor area is for men and guests. Meanwhile each Bale Bontar has different floor plan. However, every house has a room for preparing the ritual offerings and most of the houses still use traditional material for structure. In Bale Bontar, almost all rooms can be entered by men. But there is still a room for making the ritual offerings that men could not enter when it is used for ritual. Bale Tani could still be preserved by the system of pattern relative. Moreover, there is also awiq-awiq as customary law that still has a big influence in traditional house preservation. However, conservation policy is recommended to be established to create a sustainable traditional house and preserve the culture from extinction.

\section{Acknowledgements}

This research was carried out with the support of Grant-in-Aid for Scientific Research in Japan: Research on conservation methods by traditional custom system - International collaboration research on conservation of the tropical wooden structures (15H02636).

\section{Conflict of interests}

The authors declare that there is no conflict of interests regarding the publication of this paper.

\section{References}

Aziz, Y. (2014). Ruang 8 Volume 2: Preservasi (Aksi). Jakarta: Architectural E-magazine. Retrieved from https://issuu.com/akudanruang/docs/ruang_8_aksi_fix

Badan Pusat Statistik Provinsi Nusa Tenggara Barat. (2015). Average Number of Rain and Rainfall by Districts in Lombok Tengah Regency. Retrieved from https://lomboktengahkab.bps.go.id/subject/153/geografi. html\#subjekViewTab4 
Badan Pusat Statistik Provinsi Nusa Tenggara Barat. (2018). Population of Nusa Tenggara Province by Regency/Municipality, 1993-2017. Retrieved from https://lomboktengahkab.bps.go.id/subject/12/ kependudukan.html\#subjekViewTab3

Budiwanti, E. (2012). Spiritual Dynamic of Balinese in Lombok: Sacred Site and Holy Water. Jakarta: Indonesian Institute of Sciences. Retrieved from http://www.academia.edu/3527785/SPIRITUAL_DYNAMICS_OF _BALINESE_IN_LOMBOK_SACRED_SITES_AND_HOLY_WATER

Cederroth, S. (1981). The Spell of the Ancestors and the Power of Mekkah. A Sasak Community on Lombok. Sweden: Acta Universitatis Gothoburgensis.

Fathurrahman, H. L. A. (2016). Membaca Arsitektur Sasak. Mataram. Indonesia.

Sato, K. (1986). The Heart of Austronesian Houses. Retrieved from http://www.sumai.org/asia/sasak.htm

Suarsana, I. N., Purwadi, M. S., Suka, I. G., Muniarsih, A. A. A., ..., \& Hum, M. (2015). Sade Hamlet Etnography. Bali. Udayana University.

Sukawi, Z. (2010). Adaptation of Sasak Architecture Towards Tropical Climate Environment Condition: Case Study of Sade Traditional Hamlet in Lombok. Semarang: Universitas Diponegoro. Retrieved from http://eprints.undip.ac.id/32374/1/ADAPTASI_ARSITEKTUR_SASAK_TERHADAP_KONDISI_IKLIM _LINGKUNGAN-sukawi.pdf

Wakita, Y., Shuji, F., Norio, M., \& Akihito, A. (1995). Space Organization of the Settlements in Desa Bayan in Lombok Island, Indonesia. Architectural Institute of Japan.

Wirata, I. M. (2013). Transformasi Rumah Adat Suku Sasak di Dusunu Segenter, Kecamatan Bayan-Lombok Utara, Nusa Tenggara Barat. Denpasar: Udayana University.

\section{Copyrights}

Copyright for this article is retained by the author(s), with first publication rights granted to the journal.

This is an open-access article distributed under the terms and conditions of the Creative Commons Attribution license (http://creativecommons.org/licenses/by/4.0/). 